\title{
ПІДГОТОВКА ЛІКАРІВ ЗА СПЕЦІАЛЬНСТЮ “НЕОНАТОЛОГІЯ” ДЛЯ РОБОТИ В ПЕРИНАТАЛЬНИХ ЦЕНТРАХ
}

\author{
Т. В. Сандуляк, О. А. Сердцева, Т. М. Клименко, А. М. Закревський
}

Харківська медична академія післядипломної освіти

\section{PREPARATION OF DOCTORS ACCORDING TO THE SPECIALIZATION "NEONATOLOGY" TO WORK IN THE PERINATAL CENTRES}

\author{
T. V. Sandulyak, O.A. Serdtseva, T. M. Klymenko, A. M. Zakrevskyi \\ Kharkiv Medical Academy of Postgraduate Education
}

\begin{abstract}
Розглядаються необхідність та шляхи вдосконалення моделі “лікар-спеціаліст” з неонатології для перинатальних центрів. Поданий досвід роботи зі створення такої моделі в сучасних умовах реформування системи післядипломної освіти в Україні. Під час модернізації та удосконалення структури і змісту поняття “лікар-спеціаліст" для перинатальних центрів основну увагу приділено інноваційним інтерактивним технологіям навчання в реальних умовах та створенню навчальних ситуацій, впровадженню європейських норм і стандартів знань, вмінь та практичних навичок, інтеграції слухачів у світовий науковий простір.
\end{abstract}

The necessity and ways of improvement of model "Doctor-Specialist" in Neonatology for perinatal centres are considered. The experience of creating and developing of the model under modern conditions of reformation in the system of postgraduate education in Ukraine is laid out. During upgrading and improvement of structure and content of the concept "doctor-specialist" for perinatal centres, the main attention was paid to innovative interactive technologies of teaching under conditions of real and model situations, provision of European standards and terms of knowledge, abilities and practical skills, integration of students to the Global Scientific Space.

Вступ. В нашій країні створена та зростає мережа перинатальних центрів (ПЦ) [4] - система оптимальної регіоналізації медичної допомоги матерям та новонародженим. ПЦ третього рівня якості медичної допомоги, високоспеціалізованої та висококваліфікованої, з адекватним фінансовим та матеріальним забезпеченням, працюють в 16 областях, а до 2015 року планується їх відкриття в усіх регіонах України $[1,2]$. В штатному розкладі центрів збільшено кількість неонатологів, акушерів-гінекологів, терапевтів і включені посади ендокринолога, дитячих хірурга, невролога, анестезіолога, кардіолога, офтальмолога та сурдолога $[5,6]$.

Усі вищеперераховані лікарі повинні володіти великим обсягом знань, вмінь та навичок з формування здорового способу життя та виховання населення дітородного віку, планування сім'ї, забезпечення нормального перебігу вагітності та безпечного материнства, надання повноцінної медичної допомоги вагітній, плоду роділлі та новонародженому. Однак сьогодні в Україні [3, 9], на відміну від країн Свросоюзу, США, Канади, Ізраїлю та ін., немає цілеспрямованої дип- ломної та післядипломної підготовки спеціалістів 3 перинатології та неонатології [3, 10, 11]. Існуючі моделі спеціаліста-неонатолога та акушера-гінеколога, програми з їхньої підготовки в інтернатурі та на циклах спеціалізації, вміщують в собі недостатньо необхідної інформації та сучасних вимог 3 перинатальної медицини. А лікарі суміжних спеціальностей, які почали працювати в ПЦ, зовсім не мають базової та післядипломної підготовки з перинатології та неонатології $[6,9,10]$. Штат ПЦ заповнюється лікарями, підготовленими в інтернатурі та на циклах спеціалізації в різних ВНЗ, на різних кафедрах та клінічних базах, без затвердженої моделі спеціаліста та її сертифікації для роботи в медичних закладах третього рівня.

В країнах з розвиненою медициною в ПЦ працюють лише лікарі із досвідом практичної роботи в такому закладі за спеціальністю "Неонатологія" не менш ніж 7-10 років. Для цього потрібна базова підготовка з загальної практики у ВН3 5-6 років, 2-3 роки навчання в інтернатурі та стажування, а після цього необхідно відпрацювати в цьому ж закладі кілька років ординатором за вибраною спеціальністю $[3,11]$.

(ㄱ Т. В. Сандуляк, О. А. Сердцева, Т. М. Клименко, А. М. Закревський 
Після такої обов'язкової практичної підготовки спеціалісти отримують допуск до інтегрованого ліцензійного іспиту з відповідної спеціальності в Асоціації лікарів, а потім - Сертифікат спеціаліста та ліцензію на право медичної діяльності [11]. Лікарі, які працюють за суміжними спеціальностями, повинні мати сертифікати спеціаліста 3 кожної з них, видані відповідними асоціаціями.

Згідно з нинішніми реаліями підготовки кадрів для ПЦ України, “спеціалістами” стають після 2-х років інтернатури або 3-місячної спеціалізації. Не маючи достатнього досвіду практичної роботи, особливо після циклів спеціалізації, в наступні 5-7 років діяльності, такий лікар, фактично, навчається на своїх помилках, доки не акумулює досвід, який неможливо отримати, працюючи в іншому медичному закладі, та спеціальні знання, які неможливо здобути у ВНЗ $[2,10,11]$.

Основна частина. В умовах реформування системи післядипломної освіти в Україні поточні проблеми та нові вимоги до модернізації та покращення структури та змісту моделі неонатолога для ПЦ вирішуються нами шляхом інтегрування слухачів до світового наукового простору, а також завдяки впровадженню у післядипломну освіту європейських норм та стандартів знань, вмінь і практичних навичок. Задля досягнення максимальної практичної підготовки лікаря на циклі спеціалізації з неонатології ми використовуємо інноваційні інтерактивні технології навчання у реальних та навчальних ситуаціях, які відпрацьовуються у малих групах на практичних заняттях у відділеннях Харківського міського перинатального центру. При цьому ми впроваджуємо та використовуємо прийняті в Свропі та затверджені в Україні Протоколи діагностики, лікування та профілактики перинатальної патології, програмовані навчальні посібники і фільми, методики набуття практичних навичок з визначенням ступеня оволодіння ними за визнаними у світі еталонами та відпрацьованими нами контрольними листами виконання процедур.

Лікарям-неонатологам, прийнятим на роботу у ПЦ після закінчення інтернатури чи спеціалізації 3 неонатології, надаємо додаткову підготовку на циклах стажування або тематичного вдосконалення в межах програми підготовки фахівця першої кваліфікаційної категорії за спеціальністю "Неонатологія". Такі слухачі отримують знання, вміння та навички, які дозволяють їм надавати необхідну допомогу новонародженим під час чергувань та проаналізувати iii ефективність, своєчасно проводити диференційну діагностику, правильно розробляти лікувально-діагностичну тактику. Зрозуміло, що надана підготовка не заміняє необхідні 5-7 років практичного досвіду, але лікарі хоча б отримують той мінімум знань, вмінь та навичок, які дозволяють їм виконувати вимоги Протоколів, прийнятих у ПЦ України та країн Євросоюзу.

В процесі формування моделі “лікар-спеціаліст" мають значення такі фактори $[3,8,9]$ : модульне навчання, тестові технології та рішення ситуаційних завдань. Для досягнення кінцевої мети навчання та отримання встановленого стандарту якості підготовки спеціаліста за короткий проміжок часу викладач повинен впроваджувати інноваційні методики викладання, використовувати проблемно-орієнтоване навчання, імітаційні системи для відпрацювання та закріплення практичних навичок, розроблені об'єктивні структуровані методи оцінки вмінь та навичок у вигляді ситуаційних завдань та алгоритмів дій $[3,8,10]$.

Інноваційний процес - це сукупність засобів, за допомогою яких педагогічна ідея трансформується в навчальне нововведення. У післядипломній освіті інноваційні технології спрямовані на цільові позитивні результати: досягнути певного стандарту навчання; формувати у слухача необхідний обсяг знань та вмінь, щоб користуватися інформацією за спеціальністю та аналізувати iї; навчити потрібних навичок згідно 3 переліком та розвинути компетентність вирішувати питання та проблеми із заданого кола.

Кафедра неонатології ХМАПО проводить навчання лікарів-педіатрів в інтернатурі з неонатології 1996 року, а на циклі “Спеціалізація з неонатології” - 2000 року. Основною проблемою під час підготовки неонатолога $є$ недостатній базовий рівень загальної клінічної підготовки випускників медичних університетів з фізіології та патології новонароджених. На засвоєння неонатології в університеті за всі роки навчання виділено лише 60 годин [7]. Практично весь перший рік навчання в інтернатурі з неонатології йде на формування понять про новонародженого, вивчення фізіологічних умов його адаптування, а також основ патології та компенсування втрачених функцій. Тільки на другому році навчання слухачі готові до проведення самостійного дослідження хворої дитини та аналізу отриманої інформації, до всеосяжного розбору та розуміння клінічних ситуацій.

Цикл спеціалізації розраховано на 3 місяці навчання. На нього мають зараховувати педіатрів з мінімальним досвідом у неонатології - 1 рік, однак на практиці головні лікарі спочатку посилають лікарів на 
спеціалізацію, а потім беруть на роботу. Що це за спеціальність та чим він буде займатися, такий слухач зрозуміє лише ближче до середини циклу, а засвоєння значного об'єму матеріалу залежить виключно від його когнітивних здібностей та пам'яті.

Програма циклу складена за модульним варіантом та вміщує такі розділи: “Організація охорони материнства та дитинства”, “Фізіологія та патологія плоду в пренатальному періоді”, “Фізіологія та патологія інтранатального періоду”, “Фізіологія та адаптація новонароджених", "Патологія доношених новонароджених", “Фізіологія та патологія недоношених новонароджених", "Інфекції пері- та неонатального періодів", "Невідкладні стани та інтенсивна терапія в неонатології" та "Первинна реанімація новонароджених". У програмі витриманий перинатальний підхід до спеціальності “Лікар-неонатолог”. Кожний модуль містить перелік актуальних проблем перинатології та неонатології, які знаходять своє відображення в лекційному матеріалі. На семінарах та практичних заняттях вивчаються усі нормативні документи МO3 України, стандарти, протоколи та найсучасніші світові тенденції у діагностиці та лікуванні новонароджених, наукові досягнення кафедри, а на клінічній базі слухачі засвоюють нові лікувально-діагностичні методики, які дозволяють закладу мати європейські показники якості праці. Практичні заняття побудовані у вигляді курації та розборів тематичних хворих 3 відпрацюванням алгоритмів диференційної діагностики, лікування, профілактики, моніторингу якості терапії та прогнозування можливих ускладнень, правильного оформлення та ведення необхідної документації. Дітям з нозологічними формами та синдромами, які потребують інтенсивної терапії, проводять стабілізацію стану та підготовку для транспортування в спеціалізовані лікувальні заклади.

Важливим напрямком у формуванні “спеціаліста 3 неонатології” ‘ інтегративний підхід до підвищення якості післядипломної освіти із забезпеченням інтерактивного викладання теоретичного курсу. Для цього на лекціях та семінарських заняттях запроваджуються інноваційні методики інтерактивного навчання з використанням проблемних ситуацій, спрямованої дискусії, “мозкового штурму”, групової динаміки, мультимедійної демонстрації навчальних фільмів та електронних посібників. На реферативних конференціях, семінарах-тренінгах, клінічних розборах та практичних заняттях за типом ділової гри викладачі та слухачі активно аналізують результати діяльності одне одного. Для візуалізації зроблених помилок хід заняття з відпрацювання навичок записують на відео- камеру або порівнюють свої досягнуті результати 3 еталонами проведення процедур, проглядаючи відеоматеріали та інші посібники з теми.

Контроль або перевірка результатів навчання є обов'язковим компонентом та проводиться на усіх етапах навчання спеціаліста. Мета перевірки результатів навчання полягає у визначенні рівня засвоєння знань, який має відповідати стандартам до неонатолога сучасного ПЦ. Ми використовуємо базисну, тематичну та фінальну перевірку рівня знань. Переваги перед традиційними формами та методами має тестовий контроль. Він допомагає раціонально використовувати навчальний час, опанувати великий обсяг змісту, швидко встановити зворотний зв'язок із слухачами, визначити результативність засвоєння матеріалу та концентруватись на темах з пропущених занять. Тестовий контроль забезпечує одночасну перевірку знань слухачів усієї групи та допомагає формувати у них мотивацію для підготовки до кожного заняття. Основними вимогами до чисельних тестових завдань на кафедрі є: тематичність, взаємозв'язок та доповнення між собою, впорядкованість за логікою або за складністю, уніфікованість форми тестів, послідовність рішення завдань від простого до складного. За кількістю завдань ми використовуємо короткі (до 20 завдань), середні (20 - 50) та довгі (до 150 завдань). За складністю: тести на розпізнання (запитання, які мають альтернативні відповіді), на відмінності (містять декілька відповідей), тести-співвідношення (пропонують знайти відмінності чи збіги в проблемі для вивчення), тестизавдання (в завданні формулюються умови та всі початкові дії, а у відповідях представлено кілька варіантів рішення). Для оцінювання та визначення рівня засвоєння знань, умінь та навичок у підготовці кожного спеціаліста запроваджені всі три рівні тестових завдань. Тести першого та другого рівнів ми використовуємо для базового контролю знань слухачів. Тести другого рівня проводяться для оцінки ступеня засвоєння основних модулів. Тести третього рівня для фінального контролю знання всього матеріалу за спеціальністю, у вигляді розв' язання задач у письмовій чи усній формі або за допомогою комп’ютерного тестування.

Особливе значення на кафедрі відведено проведенню щоденних тематичних реферативних конференцій-семінарів з включенням слухачів до розборів та обговорення складних клінічних випадків, які разом готують, представляють та проводять викладачі та слухачі. Такий підхід стимулює творчу активність та клінічне мислення лікарів, дає їм можливість 
проводити самооцінку особистих знань та досвіду, реалізує вимогу педагогічного процесу - навчання на основі практики.

Створення моделі спеціаліста з неонатології передбачає не тільки забезпечення необхідного рівня викладання теоретичного матеріалу, але й повноцінне опанування практичними навичками. Досвід засвідчив, що це можливо тільки на базі вже діючого клінічного ПЦ, що має сучасне діагностичне обладнання, де вже впроваджені новітні методики діагностики та лікування. Клінічні бази повинні бути достатніми для проведення практичної підготовки спеціалістів, мати відповідне сучасне діагностичне обладнання, набір пацієнтів з широким переліком нозологічних форм хвороб та відпрацьовані протоколи з їх діагностики та лікування, створені на основі доказової медицини. Клінічна база кафедри - Харківський міський перинатальний центр (ХМП), на який вже 20 років відбувається підготовка неонатологів, повністю відповідає європейським критеріям підготовки спеціалістів. В ХМПЦ два стаціонари - акушерський та неонатологічний. В акушерському стаціонарі 160 ліжок для вагітних, роділей і породілей та 80 ліжок для новонароджених - відділення інтенсивного спостереження за передчасно народженими та відділення сумісного перебування матері та дитини, а також консультативна поліклініка на 300 відвідувань на день. Професори та доценти кафедри неонатології разом із слухачами беруть участь у перинатальних консиліумах, клінічних розборах, проводять оцінювання пре- та перинатального ризику. Неонатологічний стаціонар включає 140 ліжок для хворих новонароджених міста Харкова, з них 12 - у відділенні інтенсивної терапії новонароджених і 128 ліжок у відділеннях для виходжування передчасно народжених, для дітей з патологією ЦНС та інфекційною патологією новонароджених. У структурі ХМПЦ знаходяться клінічні, імунологічна, бактеріологічна, біохімічна лабораторії, рентгенкабінети, відділення функціональної діагностики та УЗД, фізіотерапевтичне, відділення переливання крові, центр діагностики та лікування ретинопатій недоношених дітей, центри психологічної підтримки родини та підтримки вигодовування груддю.

На заняттях використовуються запроваджені в роботу ХМПЦ методи діагностики: нейросонографія, ехокардіографія, УЗД внутрішніх органів з допплерографією мозкового, мезентеріального, органного кровотоку, а також проводиться імунологічна діагностика внутрішньоутробних інфекцій (ПЛР та ІФА), ССЗВ (прокальцитонін, CRP) і реактивності дитини, застосовуються бактеріологічне дослідження з ідентифікацією та обліком патогенної мікрофлори, система бактеріологічного моніторингу WHONET-5,2 Baclink 2 . Лабораторії центру оснащені сучасними аналізаторами та досліджують всі необхідні клінічні та біохімічні параметри, визначають гази крові. В центрі запроваджені всі методики респіраторної терапії 3 використанням новітніх моделей апаратів ШВЛ, а також неінвазивний СРАР та високочастотна вентиляція легень, замісне введення сурфактанту.

В переліку практичних навичок, який передбачає підготовку лікаря-неонатолога, є мануальні навички, яких лікарі не можуть навчитися на пацієнтах з біоетичних міркувань. Зокрема, проведення первинної реанімації новонароджених у пологовій залі, які передбачають пряму ларингоскопію та інтубацію трахеї, венопункцію та катетеризацію вени пуповини, введення препаратів сурфактанту, лікувальну гіпотермію, різноманітні засоби оксигенотерапії та ШВЛ, операція обмінного переливання крові та інші. Для опанування ними при навчанні використовують тематичні відеоматеріали, манекени та муляжі. Такий підхід дає можливість засвоїти основні мануальні навички шляхом їхнього багаторазового відпрацювання під контролем викладача та групи. Наближення заняття до реальної практики, аналіз власних помилок за еталонами виконання процедури та відеоспостереженням допомагають якісно оволодіти технікою виконання необхідних маніпуляцій.

Висновок. Набутий нами досвід післядипломної освіти лікарів показує, що модель підготовки спеціаліста-неонатолога для перинатальних центрів України потребує перегляду та вдосконалення. В основі моделі повинні бути три складові: перша - досвід практичної роботи лікаря після закінчення ВНЗ у самому перинатальному центрі не менше ніж 2-3 роки або проходження в ньому інтернатури; друга наявність стандартних умов навчання та проходження практичної підготовки на сертифікованій клінічній базі, яка має сучасне діагностичне обладнання та лікувальні технології згідно з прийнятими у світі стандартами надання медичної допомоги в закладах третього рівня якості допомоги; третя - наявність підготовлених кадрів викладачів за спеціальністю, навчально-методичних посібників, імітаційних систем для відпрацювання основних маніпуляцій та навичок. Процес підготовки спеціаліста повинен включати інноваційні інтерактивні методи навчання. 


\section{Література}

1. Авраменко Т. В. Стан надання перинатальної медичної допомоги в Україні / Т. В. Авраменко // Неонатологія, хірургія та перинатальна медицина. -2012. - Т. II, № 1(3). C. 6-10.

2. Знаменская Т. К. Приоритетные направления развития перинатальной службы в Украине / Т. К. Знаменская // Неонатологія, хірургія та перинатальна медицина. -2011. - T. I, № 2. - C. 6-11.

3. Медична освіта у світі та Україні: додипломна та післядипломна освіта, безперервний професійний розвиток : навч. посібник для викладачів / Ю. В. Поляченко, В. Г. Передерій, О. П. Волосовець [та ін.]. - К. : Книга плюс, 2005. -384 c.

4. Про вдосконалення організації надання медичної допомоги матерям та новонародженим у перинатальних центрах : наказ МОЗ України № 726 від 31.10.2011 року.

5. Про затвердження Примірного статуту Перинатального центру зі стаціонаром та Примірного положення про Перинатальний центр у складі закладу охорони здоров'я : наказ МОЗ України № 514 від 15.08.2011 року.

6. Про внесення змін до наказу МОЗ України № 514 від 15.08.2011 року "Про затвердження Примірного статуту Перинатального центру зі стаціонаром та Примірного по- ложення про Перинатальний центр у складі закладу охорони здоров'я" : наказ МОЗ України № 160 від 12.03.2012 року.

7. Сенаторова Г. С. Викладання неонатології на додипломному етапі в умовах реформування вищої освіти / Г. С. Сенаторова, Н. С. Титова // Матеріали науково-практ. конф. 3 міжнародною участю $з$ нагоди 85-річчя ХМАПО та 30-річчя заснування кафедри неонатології. - Харків : Прапор, 2008.-С. 35-39.

8. Система забезпечення якості підготовки медичних кадрів в Україні / І. В. Булах, О. П. Волосовець, М. Р. Гжегоцький [та ін.]. -К. : Книга плюс, 2007. - 40 с.

9. Удосконалення післядипломної підготовки лікарів суміжних спеціальностей на циклі "Інноваційні технології виходжування, діагностики та лікування патології новонароджених" / Т. М. Клименко, Т. В. Сандуляк, О. А. Сердцева [та ін.] // Медична освіта. -2011.-№ 3.-С. 85-87.

10. Шунько Є.Є. Впровадження концепції подальшого розвитку перинатальної допомоги в Україні / Є. Є. Шунько // Неонатологія, хірургія та перинатальна медицина. -2012. T.II, № 2(4). - C. 11-16.

11. Trappl R. Die theoretische und praktische Einfuhrung in Wissenschaft und Medizin / R. Trappl, R. Marz // Leitschrift fur MedizinischeAusbildung. - 2002. - № 19(2). - S. 238-241.

Отримано 29.04.14 